\title{
BAHASA OIRATA, PULAU KISAR
}

\section{Nazarudin ${ }^{1}$}

FIB UI

\begin{abstract}
Abstrak
Bahasa Oirata adalah sebuah bahasa yang terancam punah yang dituturkan oleh suku Oirata di wilayah Pulau Kisar, Kabupaten Maluku Barat Daya. Sebagai sebuah bahasa dengan penutur sekitar 1500 orang, bahasa ini dianggap sebagai bahasa minoritas yang masuk dalam kategori terancam punah yang hidup berdampingan dengan bahasa Meher dengan penutur lebih dari 10.000 orang. Dengan demikian, cukup menarik untuk melihat bagaimana kedua bahasa tersebut saling berinteraksi. Berdasarkan temuan di lapangan, dapat diketahui bahwa kedua penutur bahasa ini berinteraksi dengan menggunakan bahasa Melayu Ambon. Selain itu, penelitian ini juga berfokus pada vitalitas bahasa Oirata dan deskripsi kebahasaan yang terdiri dari sistem fonologi dan proses morfologis yang terdapat dalam bahasa itu.
\end{abstract}

Kata kunci: Bahasa Oirata, penutur, terancam punah, fonologis, morfologis

\begin{abstract}
Oirata's language is one of endangered language that is use by Oirata people who live in Kisar Island, Maluku Barat Daya, in Maluku Province. As a language which is use only by 1500 speakers in the island, Oirata can be considered as minority and endangered language. In Kisar island, there is another language which is Meher's language. This language is used by more than 10.000 people in the island. One of the focus is how both of these language interact with each other. Furthermore, this research also focusing on the vitality of Oirata language dan its language karakteristik, such as phonology system dan some of its morphological process.
\end{abstract}

Keywords: Oirata's language, speaker, endangered, phonological, morphological

Penelitian ini merupakan bagian dari Proyek Unggulan PMB LIPI. 


\section{Pendahuluan}

Saat ini ada sekitar lebih dari 6000 bahasa di dunia dan hampir separuhnya diperkirakan akan mengalami kepunahan karena bahasa-bahasa tersebut sudah tidak lagi ditransmisikan ke generasi selanjutnya. Dari ribuan bahasa yang ada di dunia, sebanyak sepertiga dari jumlah tersebut terdapat di Asia, 30\% di Afrika, 3,5\% di Eropa, dan sekitar 15 persen terdapat di wilayah Amerika Selatan dan Amerika Utara (Grenoble, 2011: 28 dalam Austin and Sallabank, 2011). Bahasa Oirata yang digunakan oleh suku minoritas Oirata di Pulau Kisar termasuk salah satu bahasa yang dianggap hampir punah oleh beberapa peneliti.

\begin{tabular}{|c|c|c|}
\hline Central Maluku & Southeast Maluku & Southwest Maluku \\
\hline Ambon Island & Kei Islands & Kisar Island \\
\hline $\begin{array}{l}\text { *Allang } \\
\text { Hila (?) } \\
\text { Hitu (?) } \\
\text { *Tulehu (?) }\end{array}$ & Ewaw & $\begin{array}{l}\text { *Kotalama } \\
\text { Meher } \\
\text { *Oirata }\end{array}$ \\
\hline Seram Island & Tanimbar Islands & Teun-Nila-Serua Group \\
\hline $\begin{array}{l}\text { Alune (?) } \\
\text { *Amahai } \\
\text { *Kamarian (?) }\end{array}$ & $\begin{array}{l}\text { Ford ate } \\
\text { Selaru (?) } \\
\text { *Selwasa (?) } \\
\text { Yamdena (?) }\end{array}$ & $\begin{array}{l}{ }^{*} \text { Nila } \\
{ }^{*} \text { Serua }\end{array}$ \\
\hline Haruku Island & Aru Islands & Babar Islands \\
\hline * Haruku & Dobo (?) & $\begin{array}{l}\text { ?Central Marsela } \\
\text { *Imroing (?) } \\
{ }^{*} \text { Southeast Babar (?) } \\
\text { *Tela (?) } \\
\text { Wetar }\end{array}$ \\
\hline $\begin{array}{l}\text { Buru Island } \\
\text { Buru (?) }\end{array}$ & & \\
\hline
\end{tabular}

$*=$

language

moribund in

Maluku $(<$

50

speakers)

(?) = unconfirmed reports of speakers

Menurut De Jong (1937), bahasa Oirata berasal dari salah satu wilayah di Timor Leste. Hal ini kemudian diperkuat dengan pendapat Greenberg (1971) yang mengatakan bahwa bahasa Oirata (Or) memiliki hubungan yang dekat dengan bahasa Makasai (Mk), Bunak $(\mathrm{Bn})$, dan Fataluku (Ft) di Timor. Selain itu, dalam penelitian yang lain Margaret Florey dan Aone van Engelenhoven dalam diskusi mereka tentang bahasa-bahasa di Maluku, bahasa Oirata telah dikategorikan ke dalam kategori moribound language. Hal ini disampaikan melalui tabel yang dibuat oleh Florey (2000) berikut ini. ${ }^{2}$

2 Lihat "Mollucan Languages in the Netherlands: Documenting Moribund Languages in an Immigrant Setting," Ogmios Newsletter, Vol. 2. 2, Spring - 1 May 2000, halaman-halaman 3-7. 
Dalam penelitian tahun ini, berangkat dari pengkategorian Florey tersebut, penelitian bahasa Oirata berfokus pada tiga permasalahan besar yang penting untuk dijawab. Salah satunya adalah apakah benar bahasa Oirata sudah bisa dikategorikan sebagai bahasa yang moribund sesuai dengan kategori tersebut? Untuk menjawab permasalahan pertama ini, dalam penelitian ini dilakukan semacam wawancara dengan menyebarkan kuesioner yang sangat sederhana untuk mengetahui jumlah keluarga yang masih menggunakan bahasa Oirata dalam kehidupan sehari-hari mereka. Selain itu, hal lain yang perlu ditilik lebih dalam pada penelitian tahun ini adalah bagaimana sikap bahasa orang Oirata itu sendiri?

Hal lain yang juga akan dipaparkan dalam penelitian ini adalah bagaimana interaksi masyarakat Oirata terhadap masyarakat berbahasa lain, dalam hal ini masyarakat Meher yang berbahasa Meher. Adakah kedua bahasa yang sudah sekian lama bertetangga ini kemudian saling mempengaruhi satu sama lain akibat adanya kontak bahasa yang cukup intens? Selain itu, pembahasan mengenai struktur kebahasaan terkait dengan karakteristik rumpun bahasa Trans New Guinea juga akan disajikan dalam laporan ini. Penyajian tersebut meliputi fonologi bahasa Oirata, sedikit temuan tentang morfologi bahasa Oirata.

\section{Metodologi}

Permasalahan dalam paparan di atas akan berusaha dijawab dalam penelitian dengan menggunakan pendekatan kualitatif. Penulis dalam penelitian ini melakukan dua kali kunjungan ke Pulau Kisar, tepatnya di Desa Oirata Barat dan Desa Oirata Timur. Selama masa penelitian, penulis tinggal di rumah penduduk selama beberapa minggu. Selama tinggal di desa Oirata Barat, penulis mengumpulkan data dengan melakukan observasi mengenai keseharian penduduk di sana dan juga melakukan survei untuk melihat situasi bahasa dan sikap bahasa penutur jati bahasa Oirata.

Pada dasarnya penelitian ini dilakukan dalam beberapa tahap utama, yaitu observasi, pengumpulan data bahasa, penyebaran kuesioner sikap bahasa, klasifikasi data-data, dan interpretasi atas data. Observasi dan pengumpulan data dilakukan di Oirata dalam waktu kurang lebih 6 minggu dengan mencari beberapa informan yang sesuai dengan kriteria penelitian. Selain itu, penulis juga melakukan dokumentasi bahasa untuk ranah pernikahan. Dokumentasi ini kemudian ditranskripsi menggunakan perangkat lunak ELAN yang dikembangkan oleh Max Planck Institute. Penulis memilih ranah perkawinan karena berdasarkan hasil pengamatan, dalam masyarakat Oirata, ranah penggunaan bahasa Oirata yang masih utuh adalah pernikahan adat. Kemudian, dari data-data yang dikumpulkan, penulis mulai melakukan klasifikasi dan analisis data tersebut.

Analisis yang dilakukan dalam penelitian ini antara lain, sikap bahasa dan situasi kebahasaan di Oirata. Selain itu, ada juga sistem fonologi bahasa Oirata dan beberapa bagian dari proses morfologis bahasa Oirata, seperti pembahasan mengenai bentuk jamak, imbuhan penanda kala, dan struktur kalimat dalam bahasa Oirata yang ketiganya dihubungkan dengan karakteristik bahasa Trans New Guinea yang diutarakan oleh beberapa peneliti sebelumnya. 


\section{Hasil dan Pembahasan}

Di Pulau Kisar, penggunaan bahasa Oirata terkonsentrasi di dua wilayah, yaitu di Oirata Barat dan Oirata Timur. Berdasarkan peta di samping, terlihat bahwa dua wilayah itu kurang dari sepertiga luas wilayah Pulau Kisar. Hal ini semakin diperkuat pula dengan sedikitnya jumlah penduduk Oirata di Pulau Kisar yang menurut data sensus penduduk tahun 2010 hanya sekitar 1566 jiwa, yang terdiri atas 555 jiwa di Oirata Barat dan 1011 jiwa di Oirata Timur.

Akan tetapi, dari jumlah penutur tadi, sebagian besar dari penduduk di kedua desa tersebut dapat dikategorikan ke dalam penutur bahasa Oirata pasif. Sebagian dari mereka sudah tidak lagi dapat menggunakan bahasa Oirata secara adat secara aktif, mereka hanya dapat mengerti isi dari tuturan adat itu.

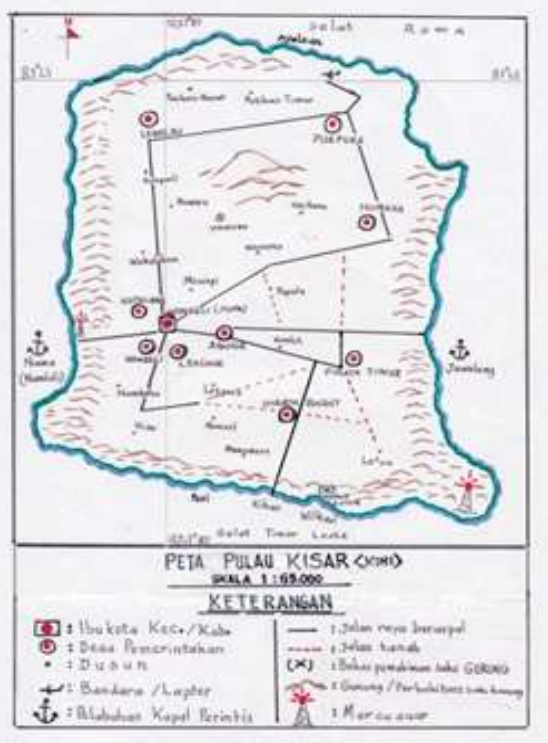

Pada dasarnya ada dua hal yang berkemungkinan menjadi penyebab berkurangnya penutur aktif bahasa Oirata. Penyebab pertama, adanya anggapan bahwa bahasa Oirata (terutama yang dituturkan dalam acara-acara adat) tidak boleh sembarangan dituturkan oleh orang lain. Hanya orang-orang yang memiliki hak (dalam hal ini orang yang ditunjuk oleh mata rumahnya sebagai juru bicara adat) yang boleh menuturkan bahasa ini. Dari wawancara dengan beberapa juru bicara adat di Oirata, dapat diketahui bahwa sebelum menjadi juru bicara adat, sebagian dari mereka terlebih dulu mendapatkan pendidikan dari orang tua mereka (yang telah lebih dulu menjadi juru bicara adat). Sementara itu, sebagian lagi mengaku tidak mendapat pendidikan dari orang tua, proses pembelajaran yang dilakukan hanya dengan mendengar tuturan-tuturan dalam upacara adat. Bagi masyarakat biasa, yang tidak berasal dari keturunan marna, ada anggapan tabu jika menggunakan bahasa Oirata seperti yang digunakan dalam upacara-upacara adat. Selain itu, faktor lain yang menjadi penyebab berkurangnya jumlah penutur aktif bahasa Oirata adalah situasi bilingualisme di wilayah Oirata itu sendiri.

Bilingualisme di kalangan penutur bahasa Oirata mampu memicu pergeseran bahasa. Menurut Grenoble (2011), ada beberapa hal yang menjadi penyebab terjadinya pergeseran bahasa. Biasanya faktor-faktor tersebut dipicu oleh adanya ketidakseimbangan antara bahasa minoritas dan bahasa mayoritas, dengan ranah komunikasi yang lebih luas dan kekuatan penggunaan yang lebih besar.

Ada dua bahasa daerah yang digunakan di Pulau Kisar, yaitu bahasa Meher dan bahasa Oirata. Kedua bahasa ini berasal dari rumpun bahasa yang berbeda, bahasa Meher merupakan rumpun bahasa Austronesia, sementara bahasa Oirata masuk ke dalam bahasa Trans New Guinea. Perbandingan kedua bahasa ini secara leksikostatistik sudah pernah dilakukan oleh Taber (1993). Dalam penelitiannya, Taber membandingkan bahasabahasa yang ada di wilayah barat daya Kepulauan Maluku. Taber melakukan penghitungan leksikostatistik terhadap 24 bahasa yang terdapat di wilayah tersebut, termasuk di dalamnya bahasa Meher dan bahasa Oirata. Berikut ini adalah peta bahasa-bahasa di wilayah Maluku Barat Daya yang diteliti oleh Taber (1993). 

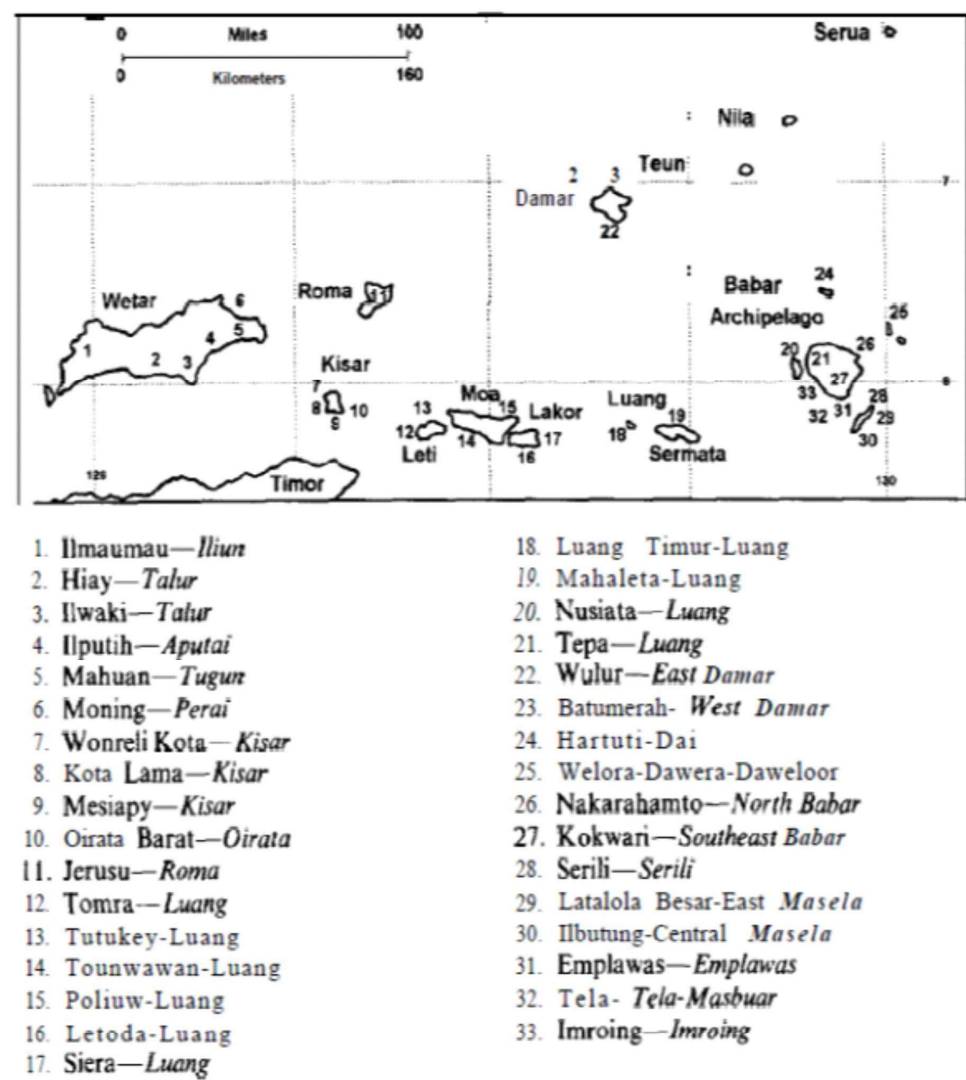

18. Luang Timur-Luang

19. Mahaleta-Luang

20. Nusiata-Luang

21. Tepa-Luang

22. Wulur-East Damar

23. Batumerah- West Damar

24. Hartuti-Dai

25. Welora-Dawera-Daweloor

26. Nakarahamto-North Babar

27. Kokwari-Southeast Babar

28. Serili-Serili

29. Latalola Besar-East Masela

30. Ilbutung-Central Masela

31. Emplawas-Emplawas

32. Tela-Tela-Masbuar

33. Imroing - Imroing

Berdasarkan hasil penghitungan leksikostatistik yang dilakukan terhadap 24 bahasa tersebut, Taber menghasilkan suatu diagram kekerabatan bahasa sebagai berikut.

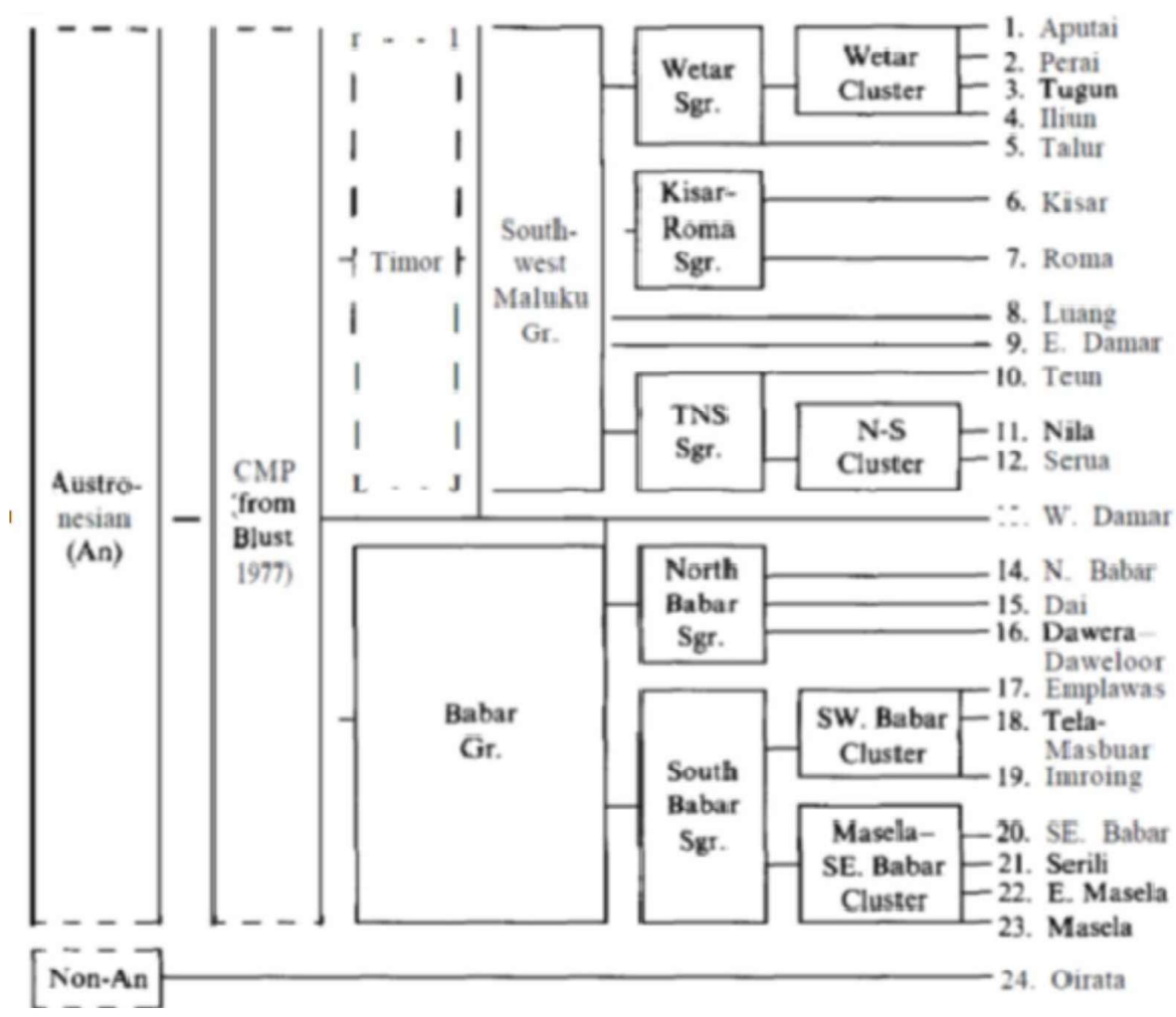


Dari diagram kekerabatan bahasa yang diutarakan oleh Taber, kita dapat melihat posisi bahasa Oirata sebagai satu-satunya bahasa non-Austronesia yang terdapat di wilayah pulau-pulau terselatan di Maluku. Dalam diagram tersebut Taber memisahkan bahasa Oirata dari 23 bahasa lain di wilayah barat daya Maluku.

"Oirata is clearly not related to the Kisar Language. Wurm and Hattori (1981) place the Oirata language under the Trans New Guinea phylum within the Timor-Alor-Pantar Stock." (Taber, 1993: 395)

Hal yang menjadi pertanyaan kemudian adalah bagaimana penutur kedua bahasa (Oirata dan Meher) ini saling berkomunikasi? Kedua penutur bahasa ini diperkirakan sudah lama sekali hidup berdampingan. Hal ini tentu saja menyebabkan adanya sentuh bahasa yang memungkinkan terjadinya perubahan pada masing-masing bahasa. Beberapa dari informan mengatakan bahwa mereka dapat mengerti bahasa Meher meskipun tidak menggunakannya secara aktif. Di sisi lain, penutur bahasa Meher tidak dapat mengerti bahasa Oirata, bahkan sebagian dari mereka menyebutnya sebagai bahasa "orang mati". Interaksi antara kedua suku tersebut dijalin menggunakan bahasa Melayu Ambon.

Fakta bahwa bahasa Oirata mengadopsi atau menyerap kosakata dari bahasa asing cukup terlihat dalam penggunaan bahasa sehari-hari. Pengaruh penjajahan Portugis membekas dari segi bahasa yang terlihat dari kosakata dalam bahasa Oirata. Penyerapan dari konsep-konsep baru yang dibawa oleh penjajah, seperti dalam bidang pendidikan, kata "iskolo" [iskolo] merupakan bentuk serapan dari bahasa Portugis untuk 'sekolah', dan "kadere" [kaţєrع] untuk 'kursi'.

Masyarakat Oirata dapat masuk ke dalam kategori masyarakat yang multilingual. Mereka menggunakan bahasa Melayu Ambon dalam kehidupan sehari-hari, terutama jika bertemu dan berbicara dengan orang non-Oirata. Selain itu, mereka menggunakan bahasa Indonesia sebagai bahasa pengantar pendidikan di sekolah. Beberapa informan mengatakan bahwa mereka menggunakan bahasa Oirata hanya dengan sesama orang Oirata. Bahkan, beberapa responden yang berusia di atas 60 tahun mengaku menggunakan bahasa Oirata jika berbicara dengan anggota keluarga mereka. Namun, uniknya sebagian dari mereka melakukan alih kode ke dalam bahasa Melayu Ambon ketika mereka berbicara dengan cucu mereka. Berdasarkan hal itu, dapat dikatakan bahwa sebagian penutur bahasa Oirata sudah tidak lagi mentransmisi bahasa Oirata kepada anak cucu mereka.

Pada dasarnya penggunaan bahasa Oirata, di kalangan sesama orang Oirata, dalam kehidupan sehari-hari cukup intens. Bahkan, penggunaan bahasa Oirata sudah sampai ke ranah religi karena bahasa Oirata juga sudah mulai digunakan di kalangan gereja, melalui penerjemahan lagu-lagu gereja dan penyampaian khotbah dalam bahasa Oirata. Fakta ini bertentangan dengan argumen Mandala (2010) yang mengatakan bahwa gereja merupakan salah satu faktor yang menghalangi perkembangan bahasa Oirata. Dengan demikian, terlihat bahwa meskipun sentuh bahasa antara penutur bahasa Oirata dan penutur bahasa tetangga cukup tinggi, penutur bahasa Oirata masih tidak melepaskan bahasa mereka.

Hal ini senada dengan argumen Foley (dalam Thomason, 2001) yang mengatakan bahwa bukan hanya multilingualisme yang terjadi dalam komunitas penutur bahasabahasa Papua (termasuk di dalamnya bahasa-bahasa Trans New-Guinea) yang kemudian menuntun ke arah pengadopsian material linguistik dari bahasa-bahasa lain, melainkan juga ada sikap kebanggaan tersendiri terhadap bahasa mereka sehingga mereka mampu 
mempertahankan keunikan bahasa mereka dan membedakan mereka dari komunitas yang lebih dominan di sekitar mereka. Hasilnya adalah "dazzling diversity ... in spite of pervasive tendency toward convergence." (Foley, 1986; dalam Thomason, 2001: 118). Sebagai contoh, jika penutur bahasa Oirata berbicara dengan sesama penutur Oirata, mereka akan menyebut polisi sebagai ihar-laware, maksudnya, ihar(a) 'anjing' dan laware 'hitam'. Akan tetapi, mereka akan tetap menyebut polisi jika ternyata ada orang ketiga yang bukan penutur bahasa Oirata. Dengan demikian, bahasa Oirata tidak banyak dikenal oleh suku-suku lain di sekitarnya karena secara tidak langsung bahasa Oirata juga dipakai sebagai bahasa kode oleh penutur aslinya.

Tim peneliti juga menemukan kasus seperti ini ketika berkunjung ke kedua desa di Oirata. Meskipun peneliti sudah mempelajari bahasa Oirata 'makan' adalah mede / meţe/, tetapi ketika penulis bertamu ke rumah penutur Oirata, peneliti merasa bingung karena mereka kemudian menggunakan kata lain, nawa /nawa/ 'makan', ketika berbicara kepada anggota keluarganya untuk menyiapkan makanan agar tidak diketahui oleh peneliti. Berdasarkan pengamatan peneliti, ada sekitar tiga bentuk leksikal dan lebih dari satu bentuk gabungan kata yang dipakai untuk merepresentasikan makna 'makan'.

Situasi penggunaan bahasa Oirata dapat diilustrasikan dalam diagram berikut ini.

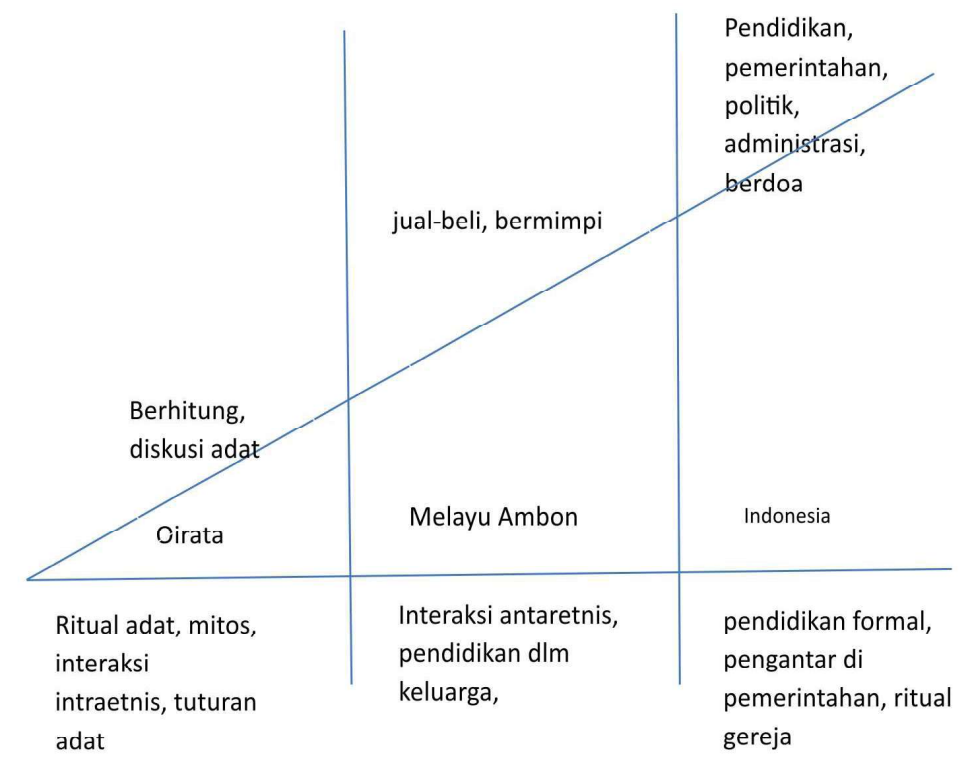

Dari diagram di atas, tampak jelas bahwa ranah penggunaan bahasa Oirata sudah semakin sedikit. Di dalam bagan tidak terdapat bahasa Meher karena bahasa Meher tidak digunakan oleh masyarakat suku Oirata dalam komunikasi.

Meskipun pada dasarnya penutur bahasa Oirata memiliki kemampuan untuk menjaga kelangsungan bahasa mereka, daya hidup bahasa Oirata dapat dianggap rendah. Jika melihat dari diagram, bahasa Oirata hanya digunakan pada ranah tertentu saja. Bahkan, sebagian informan mengatakan bahwa mereka sudah tidak lagi menggunakan bahasa Oirata ketika berbicara dengan anak-anak mereka. Dengan kata lain, transmisi bahasa Oirata antargenerasi sudah jauh berkurang sehingga bahasa Oirata dapat dianggap sebagai bahasa yang hampir punah. 
Pada dasarnya ada empat penyebab besar kepunahan bahasa menurut Crystal (2000). Keempat penyebab tersebut antara lain sebagai berikut.

1. bencana alam;

2. perang dan genosida;

3. represi yang berlebihan, sering kali mengatasnamakan persatuan nasional;

4. dominasi pilitik, ekonomi, dan sosial.

Di sisi lain, Grenoble dan Foley (2006: 18) juga mengajukan enam pembeda tingkat kepunahan sebuah bahasa. Mereka beranggapan bahwa keenam tingkat ini diperlukan untuk menangkap perbedaan tahap kepunahan bahasa, yaitu aman, berisiko, menghilang, moribund, hampir punah, dan punah.

Aman : seluruh generasi menggunakan bahasa tersebut untuk hampir semua ranah dan bahasa itu memiliki jumlah penutur yang besar. Sebuah bahasa yang aman biasanya memiliki status resmi, yang secara tipikal dapat dikatakan sebagai bahasa pengantar pemerintahan, pendidikan, dan perdagangan.

Berisiko Punah : mulai ada semacam pola yang dapat diobservasi dari penyusutan jumlah penutur. Penggunaan bahasa ini mulai terbatas hanya di beberapa domain saja atau memiliki juga penutur yang lebih sedikit jika dibandingkan dengan bahasa lain.

Hampir Hilang/lenyap : sebuah bahasa dapat masuk ke dalam kategori ini jika sudah dapat ditemukan adanya pergeseran bahasa. Hal itu masih ditambah lagi dengan berkurangnya transmisi bahasa antargenerasi. Selain itu, bahasa yang berisiko punah/lenyap ini juga secara konsekuen hanya digunakan pada domain yang terbatas, sementara bahasa yang dominan mulai digunakan dengan persentase yang lebih besar.

Moribund : Bahasa tersebut sudah tidak lagi ditransmisikan kepada anak-anak sehingga penggunanya berkurang secara konsisten.

Hampir punah : hanya sedikit penutur dari generasi tua yang masih tersisa.

Punah : tidak ada penutur

Bahasa Oirata sendiri, berdasarkan pendapat ini, dapat dikategorikan ke dalam bahasa yang hampir hilang atau lenyap. Tahap ini cocok untuk menggambarkan situasi bahasa Oirata saat ini karena dalam bahasa Oirata sudah mulai terjadi pergeseran, domain penggunaan bahasa Oirata sudah semakin sedikit, sementara masyarakat Oirata menggunakan bahasa yang dominan.

Dengan demikian, klasifikasi Florey yang memasukkan bahasa Oirata ke dalam kelompok bahasa Moribund kurang tepat mengingat bahwa pada dasarnya bahasa Oirata masih memiliki transmisi antargenerasi walaupun tidak banyak.

8 | Ranah, Volume 2, Nomor 1, Juli 2013 


\subsection{Karakteristik Bahasa Oirata}

Ada beberapa ciri yang biasanya muncul pada bahasa-bahasa Trans New Guinea. Menurut Wurm (2007), ada beberapa karakteristik yang muncul pada bahasa Trans New Guinea, misalnya bahasa Trans New Guinea ini pada umumnya hanya mengenal lima vokal sederhana dengan sedikit variasi alofon. Hal ini terdapat dalam bahasa Oirata. Bahasa Oirata hanya mengenal lima vokal, yaitu/i/, /u/, /e/, /o/, dan /a/.

\begin{tabular}{|c|l|c|c|c|c|}
\hline \multicolumn{2}{|c|}{ Posisi lidah } & Depan & Tengah & Belakang & Struktur \\
\hline \multirow{2}{*}{ Tinggi } & Atas & a & & u & Tertutup \\
\cline { 2 - 6 } & Bawah & & & & Semitertutup \\
\hline \multirow{2}{*}{ Tengah } & Atas & e & & o & \multirow{2}{*}{ Semiterbuka } \\
\cline { 2 - 6 } & Bawah & & & & Terbuka \\
\hline \multirow{2}{*}{ Rendah } & Atas & & & & \\
\cline { 2 - 5 } & Bawah & & a & & \\
\hline
\end{tabular}

Berikut ini adalah pesebaran vokal dalam kosakata bahasa Oirata dapat dilihat dari tabel berikut ini.

\begin{tabular}{|c|l|l|l|}
\hline vokal & \multicolumn{1}{|c|}{ Awal } & \multicolumn{1}{|c|}{ Tengah } & \multicolumn{1}{c|}{ Akhir } \\
\hline /a/ & ahi 'ikan' & $\begin{array}{l}\text { hakane } \\
\text { mengambang' }\end{array}$ & heina'a 'tamu' \\
\hline /i/ & i'ara 'dagu' & hitin 'putih' & irimi 'hutan' \\
\hline /u/ & uhe 'tidak' & tuhurai ‘perempuan' & uru 'bulan' \\
\hline /e/ & eme 'ambil' & elewe 'dingin' & esse 'memadamkan' \\
\hline /o/ & $\begin{array}{l}\text { onhale } \\
\text { 'belum' }\end{array}$ & popote 'memotong' & $\begin{array}{l}\text { no'ono'o } \\
\text { perempuan' }\end{array}$
\end{tabular}

Berdasarkan tabel tersebut, dapat dilihat bahwa vokal-vokal dalam bahasa Oirata dapat berdistribusi lengkap, yaitu bisa menempati posisi awal kata (inisial), posisi tengah kata (medial), dan posisi akhir kata (final). Fonem-fonem tersebut direalisasikan sebagai bunyibunyi yang distingtif.

Satu hal yang dapat disebut unik dari bahasa Oirata adalah bahasa Oirata tidak mengenal adanya konsonan letupan bersuara. Berbeda dengan bahasa Indonesia, konsonan dalam bahasa Oirata cukup sederhana karena hanya mengenal 13 buah konsonan. Di antara konsonan tersebut, hanya konsonan letup retrofleks tak bersuara / $\mathrm{t} /$ yang tidak terdapat dalam bahasa Indonesia. Fonem /t/ dalam bahasa Oirata ini dalam bahasa Makasai ${ }^{3}$ direalisasikan dengan bunyi /c/. Realisasi bunyi bahasa Oirata dapat dilihat pada peta konsonan berikut ini.

Bahasa Makasai adalah bahasa yang kekerabatannya paling dekat dan paling mirip dengan bahasa Oirata. Bahasa ini digunakan di wilayah Timor Leste. 


\begin{tabular}{|c|c|c|c|c|c|c|c|}
\hline & Bilabial & Alveolar & Retrofleks & Palatal & Velar & Laringal & Glottal \\
\hline Letupan & $\mathrm{P}$ & $\mathrm{T}$ & t & & $\mathrm{k}$ & & $?$ \\
\hline Nasal & $\mathrm{m}$ & $\mathrm{n}$ & & & & & \\
\hline Trill & & $\mathrm{r}$ & & & & & \\
\hline Frikatif & & $S$ & & & & $\mathrm{~h}$ & \\
\hline Lateral & & l & & & & & \\
\hline Hampiran & w & & & $\mathrm{y}$ & & & \\
\hline
\end{tabular}

Berikut ini akan disajikan distribusi konsonan dalam bahasa Oirata.

\begin{tabular}{|c|c|c|c|}
\hline Konsonan & Awal & Tengah & Akhir \\
\hline$/ \mathbf{p} /$ & pada /pata/'soa' & $\begin{array}{l}\text { anupa /anupa/ } \\
\text { 'menyembur' }\end{array}$ & ------ \\
\hline$/ \mathbf{t} /$ & tana /tana/ 'tangan' & mete /mete/ 'makan' & ------ \\
\hline$/ \mathrm{t} /$ & dele /tele/ 'jagung' & $\begin{array}{l}\text { kodo /koto/ 'kandang } \\
\text { babi' }\end{array}$ & ------ \\
\hline$/ \mathrm{y} /$ & yayani /yayani/ 'baik' & iyar /iyar/ 'jalan' & $\begin{array}{l}\text { lapai /lapay/ } \\
\text { 'besar' }\end{array}$ \\
\hline$/ \mathbf{k} /$ & $\begin{array}{l}\text { kamsere /kamsere/ } \\
\text { 'hadiah' }\end{array}$ & kalkali /kalkali/ 'beras' & ------ \\
\hline$/ ? /$ & ----- & $\begin{array}{l}\text { le'opo /le?opo/ 'rumah } \\
\text { adat' }\end{array}$ & ----- \\
\hline$/ \mathbf{m} /$ & malare /malare/ 'pahit' & limi /limi/ 'lima' & ------ \\
\hline$/ \mathbf{n} /$ & $\begin{array}{l}\text { na'aye /na?aye/ } \\
\text { 'berenang' }\end{array}$ & mani /mani/ 'leher' & $\begin{array}{l}\text { loton /loton/ } \\
\text { 'rotan' }\end{array}$ \\
\hline$/ \mathbf{r} /$ & $\begin{array}{l}\text { ra'aye /ra?aye/ } \\
\text { 'goreng' }\end{array}$ & mara /mara/ 'pergi' & iyar /iyar/ 'jalan' \\
\hline$/ \mathbf{s} /$ & $\begin{array}{l}\text { sesele } \quad \text { /sesele/ } \\
\text { 'berdoa' }\end{array}$ & kasu /kasu/ 'hutang' & $\begin{array}{l}\text { was /was/ } \\
\text { 'sangat' }\end{array}$ \\
\hline$/ \mathbf{h} /$ & ha /ha/ 'bapak' & tuhurai /tuhuray/ 'istri' & ------ \\
\hline$/ \mathbf{l} /$ & lapai /lapay/ 'besar' & walale /walale/ 'cepat' & ----- \\
\hline$/ \mathbf{w} /$ & $\begin{array}{l}\text { wilanu /wilanu/ } \\
\text { 'beternak' }\end{array}$ & laware /laware/ 'hitam' & ------ \\
\hline
\end{tabular}

Berdasarkan penemuan dan pembuktian di atas, bahasa Oirata memiliki tiga belas fonem konsonan yang terdiri atas /p/, /t/, /t/, /k/, / /, /m/, /n/, /l/ /r/, /s/, /h/, /w/, dan /y/. Konsonan-konsonan tersebut tidak dapat berdistribusi lengkap, sebagian besar konsonan tersebut hanya dapat menempati posisi awal (inisial) dan posisi tengah kata (medial). Khusus untuk konsonan / ? / distribusinya sangat terbatas karena konsonan tersebut hanya dapat menempati posisi tengah kata atau antarvokal.

Sementara itu, Mandala (2010), dalam disertasinya mengatakan bahwa semua konsonan dalam bahasa Oirata tidak dapat berada di akhir kata. Jika ada konsonan yang berada di akhir kata, patut dicurigai bahwa kata tersebut adalah kata serapan, bukan kata asli dalam bahasa Oirata. Pendapat tersebut ternyata tidak selalu berlaku karena dalam data yang ditemukan ada pula kata yang diakhiri dengan konsonan, misalnya konsonan $r$ dan $n$ dalam bahasa Oirata dapat muncul berdistribusi di akhir kata dalam iyar 'jalan' dan 
nikin 'nyamuk'.

Hal lain yang juga cukup unik dari konsonan dalam bahasa Oirata adalah hadirnya konsonan letup retrofleks tak bersuara / $\mathrm{t} /$. Fonem ini sebenarnya tidak ditemukan pada bahasa-bahasa Trans New Guinea lainnya. Sementara itu, bahasa Meher, yang notabene adalah bahasa tetangga yang termasuk keluarga bahasa Austronesia, juga memiliki fonem $/ \mathrm{t} /$.

Dengan demikian, dapat disimpulkan bahwa di antara kedua bahasa ini sudah terjadi kontak bahasa yang sangat intens sehingga saling memengaruhi satu sama lain. Namun, masih diperlukan penelitian mendalam untuk mengatakan apakah bahasa Oirata memengaruhi bahasa Meher, atau sebaliknya. Akan tetapi, jika melihat dari frekuensi kemunculannya, fonem /t/ dalam bahasa Oirata lebih produktif jika dibandingkan dengan / $\mathrm{t} /$ dalam bahasa Meher.

\subsection{Beberapa Temuan dalam Morfologi bahasa Oirata}

Karakteristik lain dari bahasa-bahasa Trans New Guinea adalah strukturnya yang sangat kompleks, terutama proses morfologis pada verba (Wurm, 2007). Salah satu hal yang dapat dianggap kompleks dalam bahasa Oirata adalah penggunaan penanda jamak yang dapat menempel pada verba dan nomina. Contoh berikut dapat menunjukkan penggunaan imbuhan penanda jamak dalam bahasa Oirata.

\section{A : Inte maratiho!}

/inte maratiho/

Kami(pr1pl) pergi dulu!

\section{B : Marareho! \\ /marareho/ \\ $\operatorname{pergi(pl)~silakan~}$}

Berdasarkan jawaban B, kita dapat melihat bahwa jumlah objek persona dalam tuturan dapat terlihat melalui imbuhan -re- yang melekat pada verba mara yang berarti 'pergi'. Wurm (2007) menambahkan, pada bahasa Trans New Guinea jarang sekali ditemukan indikasi bentuk plural (baik berupa morfem terikat maupun morfem bebas) yang melekat pada nomina. Namun, tidak demikian halnya pada bahasa Oirata. Dalam bahasa Oirata cukup banyak ditemukan kemunculan indikasi plural pada nomina, bahkan dalam satu kalimat bisa muncul dua indikasi plural sekaligus, nomina plural dan verba plural. Hal ini dapat terlihat pada contoh berikut ini.

\section{Narara harara umarere!}

/narara harara umarere/

Ibu(pl) bapak(pl) lebih dulu(pl)

Ibu-ibu Bapak-bapak, (sudah datang) lebih dulu!

Dua contoh kalimat tersebut biasanya diucapkan untuk menyapa orang-orang yang sudah lebih dulu datang ke suatu acara. Dari kalimat yang dituturkan tersebut dapat terlihat ada tiga kemunculan bentuk plural yang diwakili oleh morfem terikat -ra (alomorf-rara) yang menjadi sufiks pada nomina na- 'ibu' dan ha- 'bapak'. Selain itu, ada pula penanda plural -re yang mengikuti verba umare. Berdasarkan hal itu, kita dapat melihat kompleksitas indikasi 
plural dalam bahasa Oirata yang dapat mengikuti nomina dan verba, bahkan dapat muncul secara bersamaan dalam satu kalimat.

Hal lain yang cukup menarik untuk ditelisik dari bahasa Oirata adalah bentuk penanda kala. Bahasa Oirata mengenal kurang lebih tiga penanda kala, yaitu lampau, kini, dan yang akan datang. Kemunculan bentuk kala ini dapat direalisasikan dalam beberapa cara, yaitu afiksasi, bentuk leksikal, serta pemendekan dan penggabungan. Afiks yang berfungsi menunjukkan kala dalam bahasa Oirata adalah akhiran -ro dan-pe'e.

1. Anutu woirata sohonme inahanawerona.

/anutu woirata sohonme inahanawerona/

Saya(sudah) Oirata bahasa(ambil) belajar(lampau)(deklaratif).

2. Antaiti woirata sohonme inahanawena.

/anta iti woirata sohon me inahanawena/

Saya(sekarang) Oirata bahasa(ambil) belajar(deklaratif).

Berdasarkan dua contoh kalimat tersebut, dapat dilihat bahwa penanda kala dalam bahasa Oirata berada mengikuti verba inahanawe 'belajar', yaitu -ro dalam inahanawerona. Selain itu, akhiran -ro dalam contoh ternyata berfungsi sebagai akhiran semi-final karena setelah -ro- ada akhiran final -na yang menandakan kalimat deklaratif. Selain imbuhan, dalam kalimat 1 juga terdapat penanda kala yang direpresentasikan melalui pemendekan dan penggabungan kata. Pronomina anutu sebenarnya merupakan penggabungan dari stem orang pertama tunggal an- 'saya' dan adverbia waktu etu 'sudah'. Kedua bentuk tersebut disatukan sehingga membentuk anutu.

$$
\begin{gathered}
\text { an }- \text { + etu }=\text { anutu } \\
\text { saya + sudah }=\text { saya sudah }
\end{gathered}
$$

Proses seperti ini juga terlihat pada contoh kedua, yaitu pada pronomina antaiti. Sama halnya dengan kasus anutu, antaiti juga merupakan hasil dari proses pemendekan dan penggabungan sekaligus. Proses tersebut dapat kita lihat sebagai berikut.

$$
\begin{gathered}
\text { ante }+ \text { aiti = antaiti } \\
\text { saya (dekl) + sekarang = saya sekarang }
\end{gathered}
$$

Berdasarkan proses tersebut, dapat kita lihat bahwa pronomina orang pertama tunggal deklaratif ante 'saya' bergabung dengan adverbia aiti 'sekarang'. Dalam penggabungan tersebut, pronomina ante mengalami pemendekan melalui pelesapan vokal akhir /e/ menjadi ant. Sementara adverbia aiti tidak mengalami perubahan sehingga bentuk pronomina orang pertama dengan kala kini menjadi antaiti.

Bentuk gabungan pronominal dengan adverbial serupa ini cukup produktif dalam bahasa Oirata, hanya saja lebih banyak muncul pada pronomina orang pertama tunggal. 


\begin{tabular}{|l|l|l|l|l|}
\hline & & \multicolumn{1}{|c|}{ Kini } & \multicolumn{1}{c|}{ Lampau } & \multicolumn{1}{c|}{ Nanti } \\
\hline an- & ante (sing1) & Antaiti & Anutu & Antono \\
\hline in- & $\begin{array}{l}\text { inte } \\
(\text { pl1excl) }\end{array}$ & Intaiti & Inutu & - \\
\hline ap- & $\begin{array}{l}\text { apte } \\
(\text { pl1 incl) }\end{array}$ & Aptaiti & Aputu & Aptono \\
\hline a- & ate (sing2) & aiti ate & etu ate & - \\
\hline i & Ite (pl2) & - & - & - \\
\hline u & uwe (sing3) & aiti ue & etu uwe & - \\
\hline wa & Waye (pl3) & aiti waye & etu waye & - \\
\hline
\end{tabular}

Sebagai contoh, bentukan lainnya dapat dilihat sebagai berikut.

Berdasarkan tabel di atas, kita dapat melihat persebaran penanda kala yang melekat pada pronomina di bahasa Oirata. Tabel distribusi penanda kala pada pronomina ini menunjukkan pesebaran adverbia penanda kala pada setiap pronomina yang terdapat dalam bahasa Oirata. Akan tetapi, dari pesebaran tersebut terdapat rumpang-rumpang yang belum terisi karena data yang diperoleh masih kurang lengkap. Selain itu, ketika peneliti menanyakan perihal penggunaan penggabungan bentuk ini, beberapa informan mengaku tidak mengetahui lebih jauh lagi mengenai hal ini.

Sebagaimana yang sudah disebutkan, dalam bahasa Oirata ada dua jenis penanda kala, yaitu penggabungan dengan kontraksi antara pronominal dan adverbial serta penambahan akhiran -ro dan partikel pe'e. Akhiran -ro diletakkan di belakang verba untuk menunjukkan selesainya sebuah tindakan. Perhatikan contoh berikut ini.

umuro /umuro/ 'sudah mati'

umuron /umuron/ '(orang) yang (sudah) mati'

medero /meţero/ 'sudah makan'

inusaro /inusaro/ 'sudah mandi'

inahanawerona /inahanawerona/ 'sudah belajar (deklaratif)'

Pada contoh di atas terlihat akhiran -ro melekat pada verba umu, mede, inusa, dan inahanawe. Pada kata umu dan inahanawe, kata jadian umuro dan inahawero kemudian mendapat afiksasi lagi. Kata jadian umuro mengalami derivasi melalui pelekatan afiks $-n$ di akhir yang berfungsi mengubah verba lampau umuro menjadi nomina umuron. Sementara itu, verba lampau inahanawero mengalami infleksi melalui pelekatan akhiran penanda kalimat deklaratif -na menjadi inahanawerona. Dengan demikian, melalui kedua contoh tadi dapat disimpulkan bahwa pada dasarnya setelah sebuah kata dalam bahasa Oirata mendapat penanda kala, kata jadiannya masih memungkinkan untuk mendapat proses morfologis tambahan, dalam contoh mengalami derivasi dan infleksi.

De Jong (1935) dalam penelitiannya tentang bahasa Oirata mengatakan hanya ada dua kala dalam bahasa Oirata yang memiliki bentuk khusus, yaitu kala lampau dan kala

4 Menurut De Jong, ro dikategorikan ke dalam kata utuh. Sementara itu dari data yang ditemukan di lapangan, bentuk ro lebih cocok jika dikategorikan sebagai morfem terikat yang berfungsi sebagai imbuhan karena independensi morfem tersebut sangat terbatas. Keterbatasan itu terjadi karena -ro hanya melekat pada kata dari kelas tertentu saja, yaitu verba, dan maknanya lebih bersifat gramatikal sehingga lebih cocok jika disebut sebagai imbuhan daripada kata. 
nanti. Masih menurut De Jong (1935: 209), penanda lampau direalisasikan dengan kata $r \mathrm{O}^{4}$. Sementara penanda nanti direalisasikan dengan dua cara, yaitu partikel so dan pe'e. Partikel so dalam bahasa Oirata berfungsi untuk mengekspresikan sesuatu atau kegiatan yang diharapkan akan terjadi. Partikel ini dapat dikategorikan ke dalam preposisi karena biasanya terletak di depan mendahului verba. Sementara partikel lain yang juga dipakai untuk mengekspresikan suatu kegiatan yang akan berlangsung di masa yang akan datang adalah postposisi pe'e. Postposisi ini biasanya muncul setelah verba. Contoh penggunaannya dapat kita lihat sebagai berikut.

So anut inamire.

/so anutu inamire/

Nanti saya(sudah) (di sini)duduk

Saya nanti sebaiknya duduk di sini.

Apte so ina me adaluku.

/apte so ina $\mathrm{m} \varepsilon$ aţaluku/

Kami nanti apa ambil jawab.

Apa yang nanti sebaiknya kami jawab.

Hale, ina mara pe'ena?

/hale ina mara pe?ena/

Bapak, ke mana pergi akan(mau)?

Bapak mau pergi ke mana?

Berdasarkan dua contoh kalimat tersebut ada beberapa hal yang dapat diangkat. Pada contoh kalimat satu, so 'nanti' diikuti oleh pronomina lampau anutu 'saya sudah'. Sementara itu, pada contoh kalimat kedua, so mengikuti pronomina deklaratif apte. Dari kedua contoh tersebut, terlihat bahwa karakteristik so mirip seperti preposisi yang mendahului nomina. Sementara itu, dalam contoh selanjutnya pe'e lebih terlihat sebagai postposisi karena posisinya dalam kalimat berada setelah verba.

Sebagaimana yang sudah dijabarkan sebelumnya, karakteristik bahasa-bahasa Trans New Guinea menurut Wurm adalah sistem fonologi yang sederhana dengan sistem morfologi yang kompleks, di antaranya indikasi jamak yang melekat pada verba dan jarang terdapat indikasi jamak yang terdapat pada nomina. Karakteristik tersebut ternyata dapat ditemukan di bahasa Oirata. Bahasa Oirata memiliki tiga belas fonem konsonan yang terdiri atas /p/, /t/, /t/, /k/, / //, /m/, /n/, /l/ /r/, /s/, /h/, /w/, dan /y/ dan lima vokal, yaitu /i/, /u/, /e/, /o/, dan /a/. Hanya saja, dalama bahasa Or, indikasi penanda jamak bisa terdapat pada verba dan juga pada nomina, atau bahkan keduanya sekaligus dalam satu kalimat. Selain itu, dalam bahasa Oirata juga ditemukan adanya sistem penanda kala yang cukup kompleks karena penanda tersebut tidak hanya melekat pada verba, tetapi melekat juga pada pronominal melalui kontraksi yang terjadi antara pronomina dan adverbia waktu. 


\section{Simpulan dan Saran}

Bahasa Oirata adalah sebuah bahasa yang dituturkan suku minoritas Oirata di Pulau Kisar. Hal yang menarik dari penelitian ini adalah bagaimana bahasa Oirata beradaptasi dengan bahasa-bahasa di sekitarnya yang notabene seluruhnya adalah bahasa Austronesia. Persinggungan antara dua bahasa yang berbeda rumpun ini rupanya menghasilkan adanya kontak bahasa yang kemudian berpengaruh terhadap bahasa itu sendiri, misalnya mulai muncul peminjaman kosakata. Kontak bahasa tersebut ternyata bukan hanya terjadi antara bahasa Oirata dan bahasa Meher saja, bahasa-bahasa lain seperti bahasa Belanda, Portugis, dan bahasa Melayu Ambon pun juga memiliki andil sebagai bahasa pendonor bagi bahasa Oirata. Bahasa Oirata modern sekarang ini kaya dengan kosakata pinjaman dari bahasa In, Bel, Por, Ks dan Am yang banyak di antaranya diadopsi tanpa melalui proses adaptasi. Sentuh bahasa yang terjadi antara bahasa Oirata dengan bahasa-bahasa lain tersebut pada dasarnya dapat juga dikatakan sebagai usaha untuk memperkaya khazanah perbendaharaan kata dalam bahasa Oirata.

Dari sudut pandang penggunaan bahasa, bahasa yang kemudian memiliki dominasi dalam kontak bahasa justru bukanlah bahasa daerah dari suku mayoritas yang terdapat di Pulau Kisar. Pada kasus bahasa Oirata, perkembangan daerah yang cukup pesat menyebabkan masyarakat Oirata harus bersaing dengan bahasa Melayu Ambon dan bahasa Indonesia.

Bahasa Or seperti halnya bahasa Trans New Guninea lainnya, memiliki vokal dan konsonan yang cukup sederhana, yaitu hanya mengenal lima vokal, /i/, /u/, /e/, /o/, dan /a/. Sementara itu, bahasa Or tidak memiliki konsonan letup bersuara dalam daftar kosakata yang peneliti temukan di lapangan. Sementara itu, tiga belas fonem konsonan terdiri atas /p/, /t/, /t/, /k/, / //, /m/, /n/, /l/ /r/, /s/, /h/, /w/, dan /y/. Selain ciri fonologis, bahasa Trans New Guinea dikenal dengan kompleksnya morfologi bahasa Oirata, misalnya dengan adanya penanda jamak pada pronomina.

Penelitian kebahasaan di bahasa Oirata masih menyisakan banyak hal yang dapat digali lebih dalam. Penelitian ini merupakan salah satu dari penelitian-penelitian tentang bahasa Oirata yang mau punah dari sudut pandang yang tidak luas. Tindakan revitalisasi untuk menjaga keberlangsungan bahasa ini sangat perlu untuk dilakukan. Dengan demikian, melalui sumbangan yang sedikit dari penelitian ini diharapkan dapat menjadi bahan referensi atau bahkan masukan untuk pelestarian bahasa-bahasa yang mau punah. 


\section{Daftar Pustaka}

Capell, A. 1944. "People and Language of Timor". Oceania, vol. 14, no. 4. Oceania Publications, University of Sydney.

Crystal, David. 2000. Language Death. Cambridge: Cambridge University Press.

De Josselin de Jong, J.P.B. 1937. Studies in Indonesian Culture[.] Oirata. A Timorese Settlement on Kisar. Amsterdam: Uitgave van de N.V. Noord-Hollandsche Uitgevers-Maatschappij.

Florey, Margaret Florey and Aone van Engelenhoven. 2000. “Mollucan Languages in the Netherlands: Documenting Moribund Languages in an Immigrant Setting," Ogmios Newsletter, Vol. 2. 2, Spring - 1 May.

Hoffman, John. 1979. "A Foreign Investment: Indies Malay to 1910", Indonesia 27 (April).

Hoed, Benny H. 2011. "Ekologi Bahasa, Revitalisasi Bahasa, Identitas dan Tantangan Global dalam Masyrakat Indonesia yang Multikutur," tulisan untuk "Seminar Pengembangan dan Perlindungan Bahasa-Kebudayaan Etnik Minoritas untuk Penguatan Bangsa, PMB-LIPI, Jakarta, 15 Desember."

Holton, Gary, et. al. 2012. "The Historical Relations of the Papuan Languages of Alor". Oceanic Linguistics, Vol. 51 No. 1. Hawai : Univ. of Hawai Press.

Klamer, Margaretha Anna Flora. 2002. Typical Features of Austronesian Language in Central/Eastern Indonesia. Oceanic Linguistics, volume 41, Number 2, 363-383. Hawai University Press.

Lauder, Multamia RMT. 2011. "Pengelolaan dan Pemberdayaan Bahasa-Bahasa yang Berpotensi Terancam Punah," tulisan pada Seminar Pengembangan dan Perlindungan Bahasa-Kebudayaan Etnik Minoritas untuk Penguatan Bangsa pada tanggal 15 Desember, Jakarta: Widya Graha LIPI.

Lombard, Denys. 1996. Nusa Jawa: Silang Budaya Kajian Sejarah Terpadu, Bagian I: Batas-Batas Pembaratan. Jakarta: PT Gramedia Pustaka Utama.

Mandala, Halus. 2010. "Evolusi Fonologis Bahasa Oirata Dan Kekerabatannya Dengan Bahasa-Bahasa Nonaustronesia Di Timor Leste," Disertasi Program Doktor Program Studi Linguistik, Program Pascasarjana Universitas Udayana, Denpasar.

Sahasilawane MH, Dra. Ny. F. 2008. "Sejarah Kerajaan Kisar" Jurnal Penelitian Departemen Kebudayaan dan Pariwisata, Balai Pelestarian Budaya dan Nilai Tradisional, Provinsi Maluku dan Maluku Utara.

Taber, Mark, ed. 1996. Atlas Bahasa Maluku. Ambon, Maluku: Pusat Pengkajian dan Pengembangan Maluku, Universitas Pattimura dan Summer Institute of Linguistics.

------. 1993. "Toward a Better Understanding of the Indigenous Languages of Southwestern Maluku". Oceanic Linguistics, Vol. 32 No. 2. Hawai : Univ. of Hawai Press. 